\title{
カルボキシル基含有高分子表面処理による 湿潤環境でのステンレス鋼の接着耐久性向上の検討
}

\author{
鈴木智則 ${ }^{*}$ ・湯浅 真 ${ }^{*} * *$ - 関根 功 $* * *$ \\ 山辺秀敏 ${ }^{* *}$ ・藤原敏明 ${ }^{* * *}$-天野晋武 ${ }^{* * * * *}$
}

要 旨

湿潤環境においてステンレス鋼に接着耐久性を付与するために，ポリマレイン酸 $[\mathrm{PMA}]$, アクリル酸／マ レイン酸共重合体 $[\mathrm{P}(\mathrm{AA} / \mathrm{MA})]$ およびアクリル酸／カフェ酸共重合体 $[\mathrm{P}(\mathrm{AA} / \mathrm{CA})]$ 薄膜による表面処理 を検討した。ステンレス鋼の接着において, $\mathrm{P}(\mathrm{AA} / \mathrm{MA})$ 薄膜処理では顕著な耐湿性向上効果がみられたのに 対し, $\mathrm{PMA}$ と $\mathrm{P}(\mathrm{AA} / \mathrm{CA})$ 薄膜処理ではその効果がほとんどみられなかった。カルボキシル基と金属との結 合状態を確認するためにXPS による表面分析を行った結果, P(AA/MA) のカルボキシル基とステンレス鋼 との界面にカルボン酸ア二オンの生成に伴うイオン結合が形成されていることを確認した。接着界面にイオン結 合のような強い相互作用が形成されている場合, 界面への水の侵入は考えにくく，またXPSの解析結果はステ ンレス鋼接着部の耐湿性試験の結果とよく一致することを考慮して, 接着界面の耐湿性向上はこのイオン結合に 起因すると推測された。

\section{1. 緒言}

金属材料と有機物が接着した形で使用される工業製品 は数多く, 今日, 構造用金属接着技術は様々な工業にお いて欠くことのできない接合技術である。塗装された金 属材料においても接着は極めて重要な要素技術であり, 広義には接着製品に含まれる。こうした金属の接着, 塗 装技術は，有機物サイドおよび金属サイドの双方の技術 進歩により，ここ数十年で工業的にも格段の進歩を遂げ てきた。これに伴い, 両者の接点である界面での接着メ カニズムの研究に関しても国内外で進展し, 最近では界

平成 10.6 .24 受理

* 東京理科大学理工学部 千葉県野田市山崎 2641 ( ( $278-8510$ )

** 東京理科大学界面科学研究所 東京都新宿区神楽坂 1-3 (T162-8601)

*** Asea Brown Boveri (ABB) AG, ABB Corporate Research, Speyererstrasse 4, Heidelberg, Germany

**** 日新製鋼(森技術研究所 千葉県市川市高谷新町 7-1 (广272-0011)

***** 工学院大学工学部機械工学科 東京都八王子市中野町 266-1 (豆192-0015)
面の結合を分子レベルで解析する手法が開発されつつあ

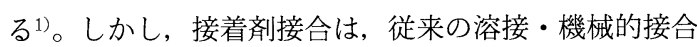
といった他の接合法に比べて耐久性に関するデー夕はま だ十分とはいえない2)。例えば，ステンレス鋼では溶接 部の応力腐食割れと表面外観の低下を防ぐ目的で接着剂 接合が注目されているが, 安定な不働態皮膜が接着剂と の親和性を阻害して接着界面への水の侵入による接着耐 久性の低下が指摘されている。それにも関わらずステン レス鋼の接着耐久性向上を目的とした表面処理に関する 研究は非常に少ない3)。一般的なステンレス鋼の接着・ 塗装用表面処理としてシランカップリング剤法および塗 布型クロメート法が知られているが, 前者では均一な処 理皮膜の形成の難しさおよび後者ではクロム化合物によ る環境污染という問題を残しており，これらに代わる無 公害なステンレス鋼の接着・塗装用表面処理技術の確立 が求められている4)。本報では, 前報3)の結果を参考に 接着耐久性を付与することを目的として, ポリマレイ ン酸 $[\mathrm{PMA}]$, アクリル酸／マレイン酸共重合体 $[\mathrm{P}(\mathrm{AA} / \mathrm{MA})]$ およびアクリル酸／カフェ酸共重合体 


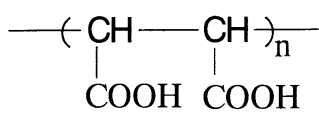

Poly(maleic acid) [PMA]

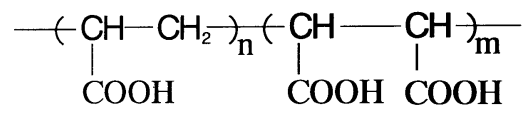

Poly((aclyric acid)-co-(maleic acid)) [P(AA/MA)]<smiles>CC(C)CCCCC(C(=O)O)c1ccc(O)c(O)c1</smiles>

Poly((acrylic acid)-co-(caffeic acid)) [P(AA/CA)]

Fig. 1 Chemical structures of various surface treating agents.

[P(AA/CA) ]（図-1）によるステンレス鋼の表面処 理を行い，湿潤環境での鋼の接着剤接合部の耐久性向上 について検討した。特に, その耐久性向上効果とステン レス鋼／処理薄膜界面構造の関連性を考察した。

\section{2. 実験}

\section{1 試料}

既報5)，6）を参考に単量体にアクリル酸（AA，和光純 薬特級), マレイン酸 (MA, 関東化学特級) およびカ フェ酸 ( $\mathrm{CA}$, 和光純薬一級), 触媒にペルオキソ二硫 酸アンモニウム (和光純薬特級), 助触媒に亜硫酸水素 ナトリウム (和光純薬特級) を用いて, 反応温度 $60^{\circ} \mathrm{C}$ のラジカル熱重合（約 1 時間）を行って PMA, $\mathrm{P}(\mathrm{AA} / \mathrm{MA})$ および $\mathrm{P}(\mathrm{AA} / \mathrm{CA})$ を得た。これら高分 子の数平均分子量 $(\overline{M n})$ をゲルパーミエーションクロ マトグラフィー（GPC， TOSOH GEL G 3000 PWXL) により求めた。

\section{2 溶液分析}

高分子の酸解離指数 $\left(\mathrm{pK}_{\mathrm{a}}\right)$ を求めるために, 水酸化 ナトリウム（和光純薬特級）による中和滴定を行った。 系の温度を $20^{\circ} \mathrm{C}$ に保った後, $\mathrm{pH}$ 滴定法により $50 \mathrm{ml}$ の高分子水溶液を $0.1 \mathrm{~N}-\mathrm{NaOH}$ で滴定し, その時のpH

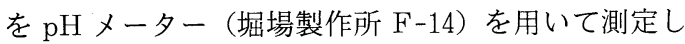
た。測定用ビュレットはミクロビュレット全容 $2 \mathrm{ml}$ 使用した。この際, 炭酸の影響を避けることと溶液を脱 気する目的から, 滴定前に 10 分間窒素ガスで通気し, さらに滴定中も通気し続けた。

\section{3 供試材および試験片作成}

ステンレス鋼としてオーステナイト系 SUS 304 2B 仕 上げ材（日本テストパネル）を使用した。化学組成は $\mathrm{C}: 0.06, \mathrm{Ni}: 8.89$, Cr: 18.75, Si : 0.54, Mn : 1. 59, P:0.03, S: 0.005, Fe : Bal. (wt\%) であっ た。

各高分子水溶液をそれぞれイオン交換水により $0.2 \%$ および $0.5 \%$ に希釈して処理液とした。処理液の濃度は 山辺ら ${ }^{7)}$ の報告により, 金属表面上で $100 \mathrm{~nm}$ 以下の薄 膜になる領域から決定した。ステンレス鋼の表面処理は 以下の順で行った。

(1) 厚さ $1.6 \mathrm{~mm}$, 幅 $25 \mathrm{~mm}$, 長さ $100 \mathrm{~mm}$ のステ ンレス鋼をアセトン中で 30 分間超音波洗浄。

（2）10\% 塩酸水溶液により 10 分間室温でエッチン グ。

（3）水道水, イオン交換水の順で洗浄。

(4) $0.2 \%$ または $0.5 \%$ の処理液に 1 分間室温で浸 漬。

（5）熱風炉中 $140^{\circ} \mathrm{C}$ で 3 分間乾燥。

以上の手順で作成した表面処理試験片を JIS K6850 に準拠して, 以下の要領で接着した。

（1）表面処理試験片 2 枚にそれぞれ，2 液主剂型ラ ジカル重合性アクリル系接着剤（電気化学工業ハード ロック C355）またはエポキシ/末端アミン変性ポリア ミド系接着剤（住友 $3 \mathrm{M}$ Scotch-Weld DP-190）のA 液と $\mathrm{B}$ 液または主剤と硬化剂をそれぞれ塗布し, 両試 験片を接触させ, クリップにより固定。

（2）試験片を室温で 7 日間かけて硬化（なお，エポ 
キシ系接着剤のみ接着剤の乾燥化, 硬化安定化等のため $100^{\circ} \mathrm{C}$ で 1 時間放置した)。

（3）上記の操作により接着試験片を得, 接着試験片 は各水準 5 本作成した。

\section{4 接着性・接着耐久性試験}

前述のように作成した試験片を温度 $60^{\circ} \mathrm{C}$, 相対湿度 $95 \%$ の恒温恒湿槽に入れ, 所定時間後に取り出し, 試験 片が室温に戻るまで約 3 時間放置し, 引張試験機（島津 製作所オートグラフ）により JIS K6850 に準拠して引 張速度 $1 \mathrm{~mm} / \mathrm{min}$ で剪断接着強度測定を行った。ま た, 試験 60 日後のサンプルを温度 $80^{\circ} \mathrm{Cで} 1$ 週間熱風乾 燥する可逆試験も行った。接合部の破壊状態は目視によ り判定した。

\section{5 表面分析}

ステンレス鋼表面に形成した表面処理皮膜の吸着・結 合状態を調べるため，X 線光電子分光分析（XPS）に より SUS 3042 B 仕上げ材上の処理薄膜の表面および その深さ方向の分析を行った。XPS 装置（島津製作 所/KRATOS, AXIS-HS) のマグネシウムK $\alpha$ 線を $\mathrm{X}$ 線源として $120 \mathrm{~W}$ (印加電圧 $12 \mathrm{kV}$ ，アノード電流 10 $\mathrm{mA}$ ) の出力で光電子脱出角度 $45^{\circ}$ で測定を行った。深 さ方向の分析は $\mathrm{Ar}^{+}$用いたスパッタリングにより 行った。

\section{3. 結果および考察}

\section{1 高分子（表面処理剤）の合成}

表-1 に合成を行った際の仕込みモル比および $\overline{M n}$ の 測定結果を示す。これより PMA は単量体/触媒のモ ル比を上げても重合度がほとんど上がっていない。これ
は MA が二つのカルボキシル基を有する 1,2-二置換の ビニル単量体で, その置換基による立体障害により単独 重合の反応性が極めて低いためと考えられる。一方, MA に比べ立体障害の少ない AA を共重合させること によって重合度が増加した。AA と MA のラジカル共 重合における各々の反応性比を算出 $\left.{ }^{8,}, 9\right)$ すると, それぞ れ 14.29 と 0.0151 という值が得られ, AA の成長が優 先して重合が進行したと推察される。また, 同じ仕込み 条件の時, $\mathrm{P}(\mathrm{AA} / \mathrm{MA})$ に比べて $\mathrm{P}(\mathrm{AA} / \mathrm{CA})$ の重合 度が非常に低い。これは CA が MA と同様, 1,2-二置 換のビニル単量体であり, 特に, CA のカテコールに相 当する非常に大きい置換基による立体障害の影響および カテコール置換基の重合禁止剤としての作用 ${ }^{10)} に よ り$ 低 重合度の高分子しか得られなかったと考えられる。

\section{2 湿潤環境でのステンレス鋼接着部の耐久性}

図-2にステンレス鋼の接着部の耐湿性に及ぼす $\mathrm{P}(\mathrm{AA} / \mathrm{CA})$ 処理の効果を示す。なお, 縦軸は各種接 着剤の比較をも考慮するため, 相対值である接着強さ保 持率（または接着強さの低下率等）ではなく, 絶対值で ある引張りせん断接着強さで示した (以下同様)。初期 接着性においては表面処理の効果はないが, 湿潤試験 のような過酷な水と温度によるストレスを加える試験で は処理効果が現れる。実際, 図-2aのアクリル系接着 剂では試験 10 日以降において, アセトン／塩酸洗浄に $\mathrm{P}(\mathrm{AA} / \mathrm{CA})$ 薄膜処理を組み合わせることで耐湿性は 向上している。また, 試験 67 日後に接着強さがほぼ初 期接着強さまで回復しているが，これは試験 60 日後の

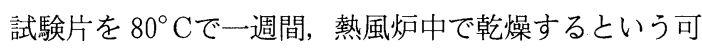
逆試験を行ったことにより界面の水分が除去されたため

Table 1 Molar ratio of components for the polymerization and number-average molecular weight $(\overline{M n})$ of polymers.

\begin{tabular}{|c|c|c|c|}
\hline Polymer & Molar ratio of monomers & Molar ratio of monomer/catalyst & $\overline{M n}$ \\
\hline PMA 1 & - & $1 / 1$ & 1. $4 \times 10^{3}$ \\
\hline PMA 2 & - & $10 / 1$ & 2. $5 \times 10^{3}$ \\
\hline PMA 3 & - & $40 / 1$ & $2.9 \times 10^{3}$ \\
\hline $\mathrm{P}(\mathrm{AA} / \mathrm{MA}) 1$ & $1 / 1$ & $10 / 1$ & $1.6 \times 10^{4}$ \\
\hline $\mathrm{P}(\mathrm{AA} / \mathrm{MA}) 2$ & $5 / 1$ & $10 / 1$ & 4. $5 \times 10^{4}$ \\
\hline $\mathrm{P}(\mathrm{AA} / \mathrm{MA}) 3$ & $5 / 1$ & $20 / 1$ & 6. $8 \times 10^{4}$ \\
\hline $\mathrm{P}(\mathrm{AA} / \mathrm{MA}) 4$ & $5 / 1$ & $40 / 1$ & 8. $9 \times 10^{4}$ \\
\hline $\mathrm{P}(\mathrm{AA} / \mathrm{MA}) 5$ & $10 / 1$ & $10 / 1$ & $2.9 \times 10^{4}$ \\
\hline $\mathrm{P}(\mathrm{AA} / \mathrm{CA}) 1$ & $5 / 1$ & $10 / 1$ & 3. $8 \times 10^{3}$ \\
\hline $\mathrm{P}(\mathrm{AA} / \mathrm{CA}) 2$ & $10 / 1$ & $10 / 1$ & 4. $3 \times 10^{3}$ \\
\hline
\end{tabular}




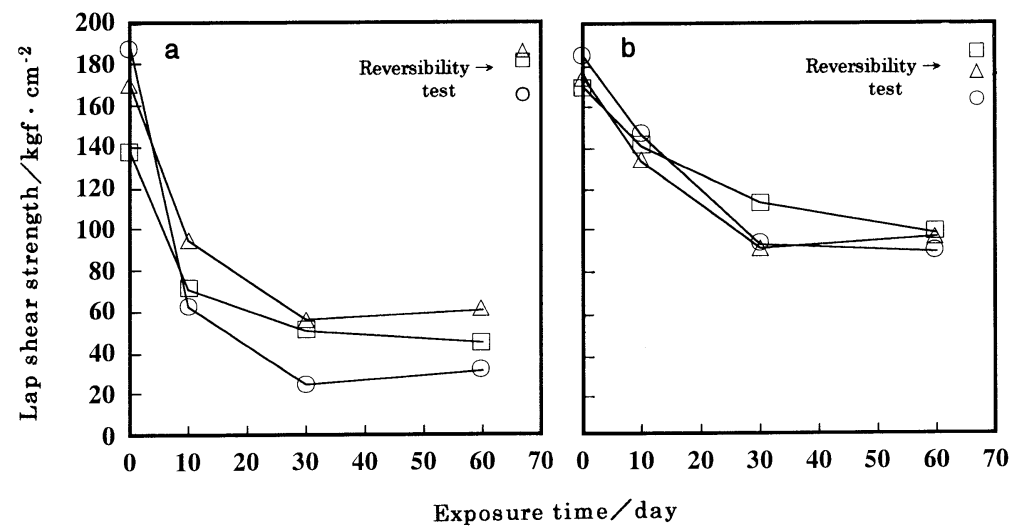

Fig. 2 Lap shear strength of (a) acrylic resin/stainless steel joints and (b) epoxy resin/stainless steel joints after being exposed to the wet environment.

$\bigcirc$, untreated (acetone $/ \mathrm{HCl}$ ); $\triangle$, treated with $0.2 \%$ aqueous solution of $\mathrm{P}(\mathrm{AA} / \mathrm{CA}) 2$;

$\square$, treated with $0.5 \%$ aqueous solution of $\mathrm{P}(\mathrm{AA} / \mathrm{CA}) 2$.

である。この試験結果より，接着強さの低下が接着剂の 劣化および処理剤の劣化によるものではなく, 界面への 水の侵入によるものであったことを裏付けている。 図-2b のエポキシ系接着剤では, 接着剤の性能上, アク リル系に比べ高い水準の接着強さが得られたが，処理効 果はほとんど得られなかった。これはアクリル系接着剤 の単量体成分が $\mathrm{P}(\mathrm{AA} / \mathrm{CA})$ の単量体成分であるアク リル酸と類似した極性の高いメタクリル酸メチルを主体 とするため, 薄膜層に接着剤の単量体成分が浸透しやす く，その結果，強勒な接着剂/薄膜界面層を形成するた

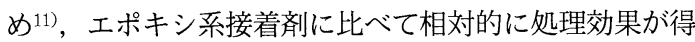
られたと考えられる。また， $\mathrm{P}(\mathrm{AA} / \mathrm{CA})$ 処理による 耐湿性の向上効果があまりみられなかった理由として は, 既報3),12)の結果と同様に, $\mathrm{P}(\mathrm{AA} / \mathrm{CA})$ の分子量 が低くカルボキシル基の吸着活性能に劣ること, および 立体障害となる大きな置換基を有する分子構造によるた めと考えられる。このように, $\mathrm{P}(\mathrm{AA} / \mathrm{CA})$ 中の $\mathrm{CA}$ は AAの利点を阻害しておりステンレス鋼に対する表面 処理剂としては不適であると考えられる。なお, 処理液 濃度を 0.2 と $0.5 \%$ に固定したが, それらの耐湿性に及 ぼす差異はほとんどなかったので以下の実験では $0.2 \%$ で行った。

図-3 および 4 にアクリル系接着剂を用いたステンレ ス鋼の接着部の耐湿性に及ぼす PMA および $\mathrm{P}(\mathrm{AA} /$ MA）処理の効果を示す。PMA 処理では処理効果が まったく得られなかった。これはPMA は分子量が低 いために鋼板に対する吸着活性能が低い上に, 酸無水物

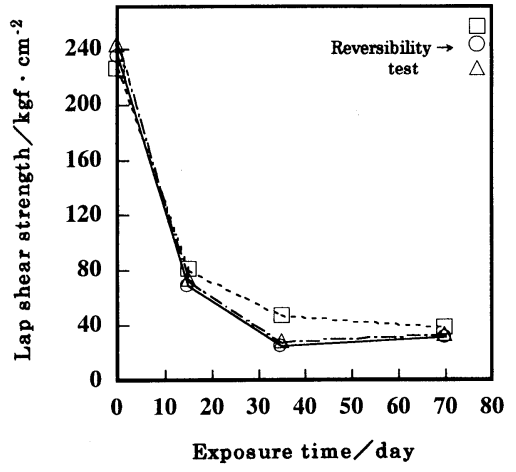

Fig. 3 Lap shear strength of acrylic resin/stainless steel joints after being exposed to the wet environment. $\bigcirc$, untreated (acetone $/ \mathrm{HCl}$ ); $\triangle$, treated with $0.2 \%$ aqueous solution of PMA $1 ; \square$, treated with $0.2 \%$ aqueous solution of PMA 3 .

を形成しやすく, その結果吸着に寄与するカルボキシ ル基の活性中心が失われるために耐湿性の向上結果 が得られなかったと考えられる。一方, 分子量の大きい $\mathrm{P}$ (AA/MA) 処理では, 分子量に依存して処理効果が 顕著に現れた。これは $\mathrm{P}(\mathrm{AA} / \mathrm{MA})$ 中の $\mathrm{AA}$ は, ラジ カル重合の成長反応において $\beta$ 付加（頭一尾付加）で起 こり, 生成高分子中の繰り返し単位の構造が規則的であ るため, $\mathrm{P}(\mathrm{AA} / \mathrm{MA})$ 分子がステンレス鋼表面へ吸着 する際にカルボキシル基の自由な回転が阻害されず，配 


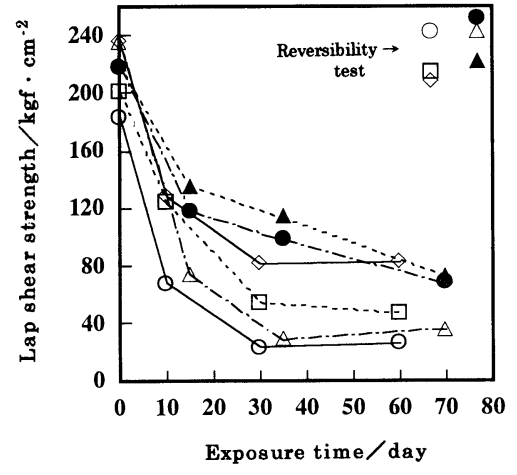

Fig. 4 Lap shear strength of acrylic resin/stainless steel joints after being exposed to the wet environment. $\bigcirc$, untreated (acetone); $\triangle$, untreated (acetone $/ \mathrm{HCl}$ ); $\square$, treated with $0.2 \%$ aqueous solution of $\mathrm{P}(\mathrm{AA} / \mathrm{MA}) 1$; $\diamond$, treated with $0.2 \%$ aqueous solution of $\mathrm{P}(\mathrm{AA} / \mathrm{MA}) 2$; treated with $0.2 \%$ aqueous solution of $\mathrm{P}(\mathrm{AA} / \mathrm{MA}) 3 ; \boldsymbol{\Delta}$, treated with $0.2 \%$ aqueous solution of $\mathrm{P}(\mathrm{AA} / \mathrm{MA}) 4$.

向性・吸着性に優れているためと考えられる。分子量に 依存した理由としては, 一分子あたりの活性点であるカ ルボキシル基の数の多さに起因すると考えられる。接着 破断面の外観観察からも, 無処理および PMA 処理で は水の侵入による鋼板と接着剤との界面破壊率が $100 \%$ であるのに対して, $\mathrm{P}(\mathrm{AA} / \mathrm{MA})$ 処理では接着剤層の 凝集破壊が残存していることから，この $\mathrm{P}(\mathrm{AA} / \mathrm{MA})$ 処理層が鋼板／接着剂界面における相互作用の向上に寄 与していることが推察された*1。アクリル系接着部の耐 湿性に処理効果の見られた $\mathrm{P}(\mathrm{AA} / \mathrm{MA}) 3$ 処理をエポ キシ系接着剤にも適用してみたところ（図-5), 試験 60 日後においても接着性の低下はほとんど見られず処理効 果が顕著に現れた。これは, 前述の $\mathrm{P}(\mathrm{AA} / \mathrm{CA})$ 処理 と比べても明らかな接着促進効果を有していることが確 認された。

\section{3 金属表面と極性有機化合物間の酸・塩基相互作用}

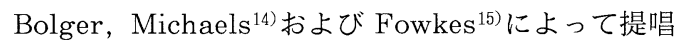
された酸・塩基相互作用の理論は，金属の接着にも適用

(脚注) ${ }^{* 1}$ 接着での破壊には界面破壊と凝集破壊があり, 接着剤 または被着材の凝集力に比べて接着界面の接着力が低い場合に接 着界面で生じる破壊を界面破壊および逆に接着界面の接着力に比 べて接着剤または被着材自体の凝集力が低い場合に接着剂層や被 着体の内部で生じる破壊を凝集破壊という13)。

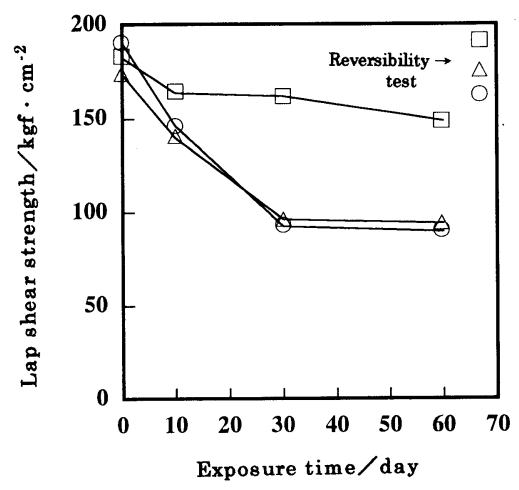

Fig. 5 Lap shear strength of epoxy resin/ stainless steel joints after being exposed to the wet environment. $\bigcirc$, untreated (acetone $/ \mathrm{HCl}$ ); $\triangle$, treated with $0.2 \%$ aqueous solution of $\mathrm{P}(\mathrm{AA} / \mathrm{CA}) 2 ; \square$, treated with 0.2 $\%$ aqueous solution of $\mathrm{P}(\mathrm{AA} / \mathrm{MA}) 3$.

できる。Bolger らの理論では，金属表面は水和酸化物 表面であり，極性有機物との相互作用の強さ（接着初期 強度）およびこれら極性有機物の水による置換のされ易 さ（接着耐久性）は金属表面の等電位点（IEPS）と有 機物の酸または塩基としての強さ（ $\mathrm{pK}_{\mathrm{a}}$ または $\left.\mathrm{pK}_{\mathrm{b}}\right)$ を用いて評価できる。オーステナイト系 SUS 304 ス テンレス鋼の最表面は非常に緻密なクロム酸化物からな る不働態皮膜に大部分が覆われており，その表面水酸基 のIEPS 值は Parks ら ${ }^{16)}$ の報告によると 7 である。 IEPSとは, 水溶液中で固体表面が電気的中性の状態と なるpH のことであり，低い IEPS 值は酸性表面を，高 いIEPS 值は塩基性表面を示す。金属表面と有機化合物 との相互作用は次式で表される。

$$
\Delta \mathrm{A}=\mathrm{IEPS}-\mathrm{pK}_{\mathrm{a}} \text { （有機酸との相互作用） }
$$

$\Delta \mathrm{A}$ が正の大きな值であるほど結合が強くイオン性 の相互作用が生じ，逆に負の大きな值であるほど結合は 弱く双極性相互作用を示す。すなわち, $\Delta \mathrm{A}$ が正の大き な值であればイオン性の相互作用が非常に強いので, 界 面に形成されている水素結合は水によって置換されな い。逆に $\Delta \mathrm{A}$ が負の大きな值であれば，イオン性の相互 作用はあり得ない14)，15)。 $\mathrm{NaOH}$ による $\mathrm{pH}$ 滴定の結果 から，（2）式を用いて PMA および $\mathrm{P}(\mathrm{AA} / \mathrm{MA})$ 水溶 液の解離度 $\alpha$ を算出した後, Henderson-Hasselbach の（3）式を利用して $\mathrm{pK}_{\mathrm{a}}$ 值を算出した ${ }^{17) 。}$ 


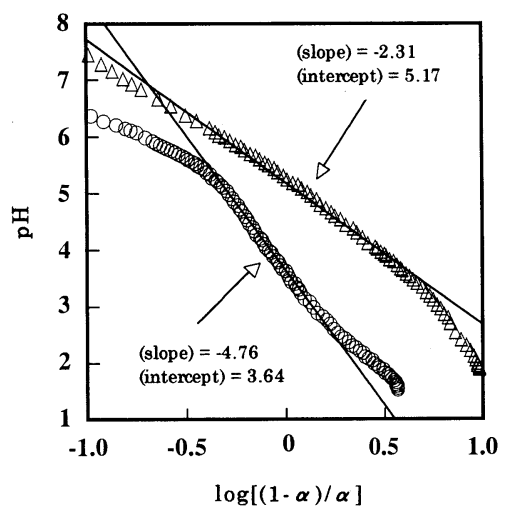

Fig. 6 Henderson-Hasselbach plots for acid dissociation constant at $20^{\circ} \mathrm{C}$. $\bigcirc$, aqueous solution of PMA $3 ; \triangle$, aqueous solution of $\mathrm{P}(\mathrm{AA} / \mathrm{MA}) 3$.

$\alpha=\left(10^{-\mathrm{pH}}-10^{\mathrm{pH}-\mathrm{pKw}}+\frac{\mathrm{T} \cdot \mathrm{N}_{\mathrm{NaOH}}}{\mathrm{V}+\mathrm{T}}\right) \cdot \frac{\mathrm{V}+\mathrm{T}}{\mathrm{V} \cdot \mathrm{N}_{\mathrm{p}}}$

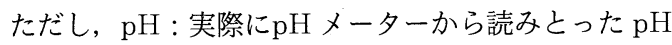
值, $\mathrm{pK}_{\mathrm{w}}$ : 水のイオン積 $\left(20^{\circ} \mathrm{C}\right.$ では 14.17$), \mathrm{T}$ : 滴下 した $\mathrm{NaOH}$ の体積, $\mathrm{V}$ : 滴下開始前の適量, $\mathrm{N}_{\mathrm{NaOH}}$ : 滴下する $\mathrm{NaOH}$ の規定度および $\mathrm{N}$ : 処理水溶液の規定 度である。

$\mathrm{pH}=\mathrm{pK}_{\mathrm{a}}+\mathrm{n} \cdot \log \frac{\alpha}{1-\alpha}$

(3) 式は $\mathrm{pH}$ と $\log [\alpha /(1-\alpha)]$ が傾き $\mathrm{n}$ の直 線関係にあることを意味するが，この直線関係は $\log [\alpha /(1-\alpha)]$ が- 1 から +1 の間で成立する ${ }^{17)}$ 。 $\mathrm{n}$ はポリカルボン酸の解離基間に働く相互作用力の強さ を表す定数である。図-6に Henderson-Hasselbach プロットを示す。これより PMA 3 では $\mathrm{pK}_{\mathrm{a}}=3.64$ お よび $\mathrm{n}=4.76$ であり, $\mathrm{P}(\mathrm{AA} / \mathrm{MA}) 3$ では $\mathrm{pK}_{\mathrm{a}}=5.17$ および $\mathrm{n}=2.31$ となる。したがって，（1）式より

PMA 3 の場合 : $\Delta \mathrm{A}=7-3.64=3.36$

$\mathrm{P}(\mathrm{AA} / \mathrm{MA}) 3$ の場合 : $\Delta \mathrm{A}=7-5.17=1.83$ となり， $\Delta \mathrm{A}$ 值がそれぞれ正の值になることから, 酸 塩基相互作用が期待され，イオン結合形成の可能性があ ることを示唆している。ゆえに，ステンレス鋼表面のク ロム酸化物の表面水酸基が（4）式に示すカルボキシル 基との酸塩基相互作用を通じて, 接着部の耐湿性の向上 に寄与する可能性 ${ }^{18)}$ は高いと考えられる。

$>\mathrm{Cr}-\mathrm{OH}+\mathrm{HOOC}-\rightarrow>\mathrm{Cr}-\mathrm{OH}_{2}{ }^{+} \cdot{ }^{-}{ }^{-} \mathrm{OOC}-$

しかし， $\Delta \mathrm{A}$ 值が PMA $3>\mathrm{P}(\mathrm{AA} / \mathrm{MA}) 3$ となるこ とより PMA 3 の方が強い相互作用を示すと予想される

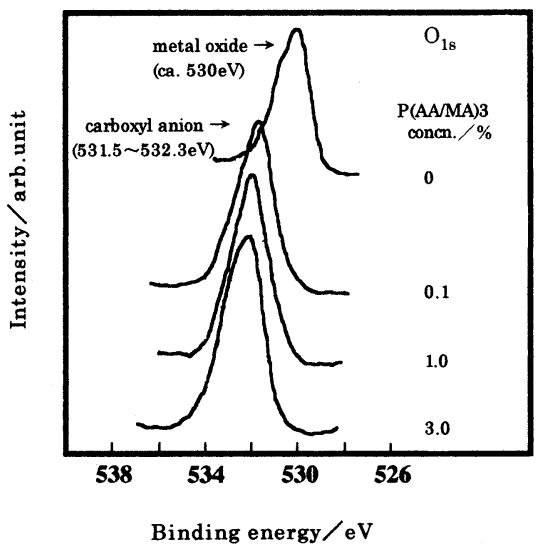

Fig. $7 \quad \mathrm{O}_{1 \mathrm{~s}}$ XPS spectra of SUS 304 surfaces treated with $0-3.0 \%$ aqueous solutions of $\mathrm{P}(\mathrm{AA} / \mathrm{MA}) 3$.

がこれは耐湿性評価結果と矛盾する。そこで n に着 目すると $\mathrm{PMA} 3>\mathrm{P}(\mathrm{AA} / \mathrm{MA}) 3$ であることより, PMA 3 の方が解離基間に働く相互作用力が強く, 鋼板 の表面水酸基との相互作用に寄与するカルボキシル基の 割合が少ないことが予想される。これは MA がシス配 置に2つのカルボキシル基を有するため分子内で水素結 合を形成しやすく，その結果生じたアニオン（第一段階 の解離）の陰電荷がキレート環に分散されて安定化する ことに起因すると考えられる。

\section{$3.4 \mathrm{XPS}$ による P(AA/MA) 薄膜処理層構造の解 析}

図-7 および表-2 に $\mathrm{P}(\mathrm{AA} / \mathrm{MA}) 3$ 薄膜処理したステ ンレス鋼表面の $0_{1 \mathrm{~s}}$ 電子の結合エネルギーの XPS スペ クトルおよびその解析結果を示す。これより結合エネル ギーが処理液濃度の増加とともに高エネルギー側へシフ トしていることから, 処理液中のカルボキシル基がステ ンレス鋼との界面において強い相互作用を受けており, 処理液濃度の増加とともにその処理層の厚みが増してい ること ${ }^{12)}$ が予想される。このようなカルボン酸の酸素原

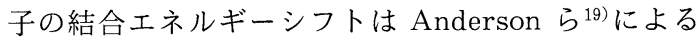
と, 鋼板表面の水酸基とカルボキシル基との電子の移動 を伴う相互作用によるもので，カルボン酸は水酸基より 電子を受け取り, カルボン酸アニオンを形成しているた めであるとされている。すなわち, カルボン酸アニオン とプロトン化した金属表面水酸基との間にイオン結合が 形成されていることが推測される。

図-8に無処理（アセトン／HCl）および $0.2 \% の$ 
Table 2 Peak position of $\mathrm{O}_{1 \mathrm{~s}}$ spectra and chemical state of $\mathrm{t}$ reated stainless steel surface.

\begin{tabular}{ccc}
\hline $\begin{array}{c}\text { Concn. of } \begin{array}{c}\text { P(AA/MA) } 3 \\
(\text { wt\% })\end{array} \\
0\end{array}$ & $\begin{array}{c}\text { Peak position } \\
(\mathrm{eV})\end{array}$ & Chemical state \\
\hline 0.1 & 529.9 & oxide \\
1.0 & 531.5 & carboxyl anion \\
3.0 & 531.9 & $" \prime$ \\
\hline
\end{tabular}

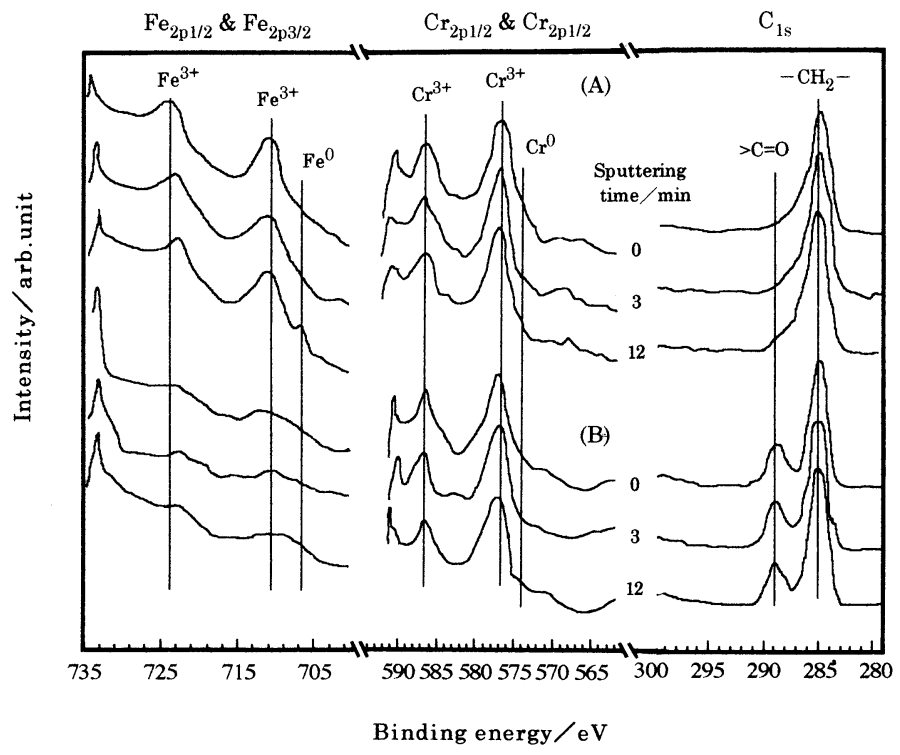

Fig. $8 \mathrm{Fe}_{2 \mathrm{p}}, \mathrm{Cr}_{2 \mathrm{p}}$ and $\mathrm{C}_{1 \mathrm{~s}}$ XPS spectra of SUS 304 untreated (A) and treated (B) with aqueous solutions of $\mathrm{P}(\mathrm{AA} / \mathrm{MA}) 3$.

$\mathrm{P}(\mathrm{AA} / \mathrm{MA}) 3$ で処理したステンレス鋼の $\mathrm{Fe}_{2 \mathrm{p}}, \mathrm{Cr}_{2 \mathrm{p}}$ および $\mathrm{C}_{1 \mathrm{~s}}$ の XPS スペクトルを示す。無処理の $\mathrm{Fe}_{2 \mathrm{n} 3 / 2}$ スペクトルに現れた $710.7 \mathrm{eV}$ のピークおよび $\mathrm{Fe}_{2 \text { p1/2 }}$ スペクトルに現れた $724.0 \mathrm{eV}$ のピークはそれ ぞれ $\mathrm{Fe}_{2} \mathrm{O}_{3}$ の結合エネルギーと一致している。した がって, 不動態皮膜中の $\mathrm{Fe}$ は $\mathrm{Fe}_{2} \mathrm{O}_{3}$ 中の $\mathrm{Fe}$ と同じ酸 化状態 $\left(\mathrm{Fe}^{3+}\right)$ で存在していると考えられる。一方で $\mathrm{P}(\mathrm{AA} / \mathrm{MA}) 3$ 処理した鋼板ではそれらのピークの大部 分が消失した。無処理および $\mathrm{P}$ (AA/MA) 処理の $\mathrm{Cr}_{2 \text { s } 3 / 2}$ スペクトルに現れた $576.7 \mathrm{eV}$ のピークおよび $\mathrm{Cr}_{2 \mathrm{p} 1 / 2}$ スペクトルに現れた $586.4 \mathrm{eV}$ のピークはそれ ぞれ $\mathrm{Cr}_{2} \mathrm{O}_{3}$ の結合エネルギーと一致している。した がって，不動態皮膜中の $\mathrm{Cr}$ は $\mathrm{Cr}_{2} \mathrm{O}_{3}$ 中の $\mathrm{Cr}$ と同じ酸 化状態 $\left(\mathrm{Cr}^{3+}\right)$ にあると考えられる。 $\mathrm{P}(\mathrm{AA} / \mathrm{MA}) 3$ 処理した鋼板でも $\mathrm{Cr}^{3+}$ のピークが消失しないことから
考えて, $\mathrm{P}(\mathrm{AA} / \mathrm{MA})$ 中のカルボキシル基は $\mathrm{Cr}$ 酸化 物の表面水酸基との間で, $\mathrm{Fe}$ のそれよりも優先的に電 子移動を伴う相互作用を引き起こしていると考えられ る。 $\mathrm{C}_{1 \mathrm{~s}}$ スペクトルに関しては，285.0eV にピークが生 じたが, 試験片表面の污染 $\left(-\mathrm{CH}_{2}-\right)$ の影響と考えら れる。 $\mathrm{P}(\mathrm{AA} / \mathrm{MA}) 3$ 処理では $288.5 \mathrm{eV}$ に $>\mathrm{C}=\mathrm{O}$ に基 づくピークが現れたが，これは無処理では見られないこ とから，洗浄に用いたアセトンの $>\mathrm{C}=\mathrm{O}$ ではなく $\mathrm{P}(\mathrm{AA} / \mathrm{MA})$ 中のカルボキシル基に相当するものであ ると考えられ，皮膜の存在が推測された。

\section{4. 結 論}

難接着性材料であるステンレス鋼に接着耐久性を付 与することを目的に，ポリカルボン酸である PMA， $\mathrm{P}(\mathrm{AA} / \mathrm{MA})$ および $\mathrm{P}(\mathrm{AA} / \mathrm{CA})$ による表面処理を施 
し，湿潤環境における鋼の接着剤接合部の而久性向上効

果について検討し，以下のような結論を得た。

(1) P(AA/CA) 薄膜を SUS 304 ステンレス鋼上 に形成させることにより，アクリル系接着剤接合部の耐 湿性が向上した。しかし， $\mathrm{P}(\mathrm{AA} / \mathrm{CA})$ 中の $\mathrm{CA}$ はそ の分子構造上，鋼板に対する配向・吸着を阻害してしま うため, 耐湿性の向上効果は $\mathrm{P}(\mathrm{AA} / \mathrm{CA})$ 中の $\mathrm{AA}$ の寄与にあるものと考えられる。

(2) PMA および P (AA/MA) 薄膜を SUS 304 ステンレス鋼上に形成させることにより, PMA の場 合，接着剤接合部の耐湿性はまったく向上しなかったも のの, $\mathrm{P}(\mathrm{AA} / \mathrm{MA})$ においてはアクリル系およびエポ キシ系接着剤接合部の耐湿性が分子量に依存して飛躍的 に向上した。

（3）XPSによるステンレス鋼との界面分析結果よ り, $\mathrm{P}(\mathrm{AA} / \mathrm{MA})$ 薄膜はそのカルボキシル基がステン レス鋼表面水酸基と電子の移動を伴う強い酸・塩基相互 作用を起こしており, その結果, 強固なイオン結合を形 成していると推測された。接着界面の耐湿性向上はこの イオン結合に起因すると考えられる。

\section{文献}

1）仲澤眞人：色材，68，424（1995).

2）山辺秀敏 : 日本接着学会誌, 29, 12 (1993).

3）山辺秀敏, 天野晋武, 藤原敏明, 加連明也 : 色 材, 69, 158 (1996).

4）山辺秀敏, 平原英俊, 森 邦夫 : 色材, 68, 404 (1995).
5）湯浅 真, 関根 功, 三本木満, 佐藤以久子, 今 濱敏信, 柴田芳昭 : 腐食防食 '92 講演集, p. 215 (1992).

6) I. Sekine, M. Yuasa, M. Sanbongi, H. Hagiuda, T. Oshibe, T. Imahama, Y. Shibata, and T. Wake : J. Electrochem. Soc., 139, 3167 (1992).

7）山辺秀敏, 堤あか权: 色材, 66, 755 (1993).

8）高分子学会編：“高分子化学の基礎第 2 版”, p. 304, 東京化学同人 (1994).

9) H. Mark, P. J. Flory, C. S. Marvel, and H. W. Melville : "High Polymers, XII, Copolymerization", Interscience, New York (1964).

10) C. C. Price: Ann. N. Y. Acad. Sci., 44, 351 (1943).

11）山辺秀敏, 天野晋武, 藤原敏明, 加連明也 : 色 材, 69, 165 (1996).

12）山辺秀敏, W. Funke : 色材, 64, 630 (1991).

13）高分子学会高分子辞典編集委員会編：“新版高分 子辞典”, 朝倉書店 (1988).

14) J. C. Bolger : "Adhesion Aspects of Polymer Coatings", p. 3, Plenum Press, New York (1983).

15) F. M. Fowkes : "Physicochemical Aspects of Polymer Surfaces”, p.583, Plenum Press, New York (1983).

16) G. A. Parks: Chem. Rev., 65, 177 (1965).

17）永澤 満, 滝澤 章：“高分子水処理剤”, p . 82, 地人書館 (1985).

18）山辺秀敏, 堤あか权: 色材, 66, 759 (1993).

19) H. R. Anderson and J. D. Swalen : J. Adhes., 9, 197 (1978). 
Investigation on the Improvement of the Adhesion Durability of Stainless Steels in Wet Environment by Surface Treatment with Polymer Containing Carboxyl Groups

Tomonori Suzuki*, Makoto YuasA*,**, Isao SeKine*,**, Hidetoshi Yamabe ${ }^{* * *}$, Toshiaki Fujiwara**** and Susumu Amano*****

${ }^{*}$ Faculty of Science and Technology, Science University of Tokyo, 2641 Yamazaki, Noda, Chiba, 278-8510, Japan

${ }^{* *}$ Institute of Colloid and Interface Science, Science University of Tokyo, 1-3 Kagurazaka, Shinjuku, Tokyo, 162-8601, Japan

***ABB Asea Brown Boveri, Corporate Research, Speyererstrasse 4, Heidelberg, Germany

****Technical Laboratories, Nisshin Steel Co., Ltd., 7-1 Koya-Shinmachi, Ichikawa, Chiba, 272-0011, Japan

*****Department of Mechanical Engineering, Kogakuin University, 266-1 Nakanocho, Hachioji, Tokyo, 192-0015, Japan

\begin{abstract}
In order to give the adhesion durability to stainless steels in wet environment, we treated the surface of stainless steels with poly(maleic acid) $[\mathrm{PMA}]$, poly((acrylic acid)-co-(maleic acid)) $[\mathrm{P}(\mathrm{AA} / \mathrm{MA})]$ and poly$(($ acrylic acid $)-c o-($ caffeic acid $))[\mathrm{P}(\mathrm{AA} / \mathrm{CA})]$. The surface treatment with $\mathrm{P}(\mathrm{AA} / \mathrm{MA})$ remarkably improved the adhesive durability of stainless steels in wet environment. However, the surface treatment with $\mathrm{PMA}$ and $\mathrm{P}(\mathrm{AA} / \mathrm{CA})$ showed little effect. The treated surfaces of stainless steels were analyzed with X-ray photoelectron spectroscopy (XPS) for the investigation of the bondings between carboxyl group and metal. The results of XPS showed a strong evidence of carboxylate anion formed as a result of ionic interaction between carboxyl group of $\mathrm{P}(\mathrm{AA} / \mathrm{MA})$ and surface hydroxyl group on oxide layer of stainless steel. The strong interaction, ionic bonding, formed at the adhesive interface was presumed to improve the adhesion of durability. The results of XPS were in good agreement with those of lap shear test.
\end{abstract}

Key-words : Adhesion, Organic polymer, Surface treatment, Stainless steel, Surface analysis 